medRxiv preprint doi: https://doi.org/10.1101/2021.12.29.21268235; this version posted January 1, 2022. The copyright holder for this preprint (which was not certified by peer review) is the author/funder, who has granted medRxiv a license to display the preprint in It is made available under a CC-BY-NC-ND 4.0 International license .

\title{
Title: Long-term risk of cancer following pregnancies complicated by vaginal bleeding
}

Elena Dudukina, ${ }^{1}$ Erzsébet Horváth-Puhó, ${ }^{1}$ Henrik Toft Sørensen, ${ }^{1}$ Vera Ehrenstein ${ }^{1}$

${ }^{1}$ Department of Clinical Epidemiology, Aarhus University and Aarhus University Hospital, Aarhus,

Denmark

\section{Corresponding author:}

Elena Dudukina

Olof Palmes Alle 43-45

8200

Aarhus $\mathrm{N}$

Email: e.dudukina@clin.au.dk

Word count: 2679

Abstract word count: 272 
medRxiv preprint doi: https://doi.org/10.1101/2021.12.29.21268235; this version posted January 1 , 2022. The copyright holder for this preprint (which was not certified by peer review) is the author/funder, who has granted medRxiv a license to display the preprint in It is made available under a CC-BY-NC-ND 4.0 International license .

\section{ABSTRACT}

Objective: To investigate an association of vaginal bleeding-affected deliveries with the long-term risk of cancer as compared with vaginal bleeding-unaffected deliveries and pregnancies ending in a termination or miscarriage.

Design: Registry-based cohort study in Denmark, 1995-2017.

Setting: Danish health and administrative registries.

Participants: Deliveries $(\mathrm{N}=37,085)$ affected by vaginal bleeding $(\mathrm{VB})$ within 20 gestational weeks among 35,517 women, VB-unaffected deliveries $(N=1,362,760)$ among 783,020 women, pregnancies ending in a termination $(\mathrm{N}=324,395)$ among 239,729 women or miscarriage $(\mathrm{N}=137,040)$ among 121,303 women.

Main outcome measures: Incidence rates (IR) per 10,000 person-years and cumulative incidence of cancer at the end of up to 24 years of follow-up, hazard ratios (HR) with $95 \%$ confidence intervals (Cls) adjusted for age, calendar year, reproductive history, history of chronic conditions, medication use, and socioeconomic factors using Cox proportional hazards regression.

Results: We observed 1,725 cancer events (IR=32.1, 95\% CI: 30.6-33.6) following VB-affected deliveries, 52,620 events (IR=31.5, 95\% Cl: 31.2-31.7) following VB-unaffected deliveries, 12,925 events (IR=30.1, 95\% Cl: 29.6-30.6) following a termination and 6,080 events (IR=34.3, 95\% Cl: 33.435.1) following a miscarriage. We found no association between VB and any cancer in comparison with VB-unaffected deliveries ( $\mathrm{HR}=0.98,95 \% \mathrm{Cl}$ : 0.93-1.03), terminations ( $\mathrm{HR}=1.00,95 \% \mathrm{Cl}$ : $0.94-$ 1.06) and miscarriages ( $\mathrm{HR}=1.04,95 \% \mathrm{Cl}: 0.94-1.14)$. Specifically, there was no increase in relative risk of breast (HR=0.94, 95\% Cl: 0.86-1.03), cervical $(0.94,0.77-1.14)$, ovarian and fallopian tube $(1.16,0.81-1.66)$, uterine cancer $(0.78,0.46-1.33)$ and other site-specific cancers across all comparisons and in sensitivity analyses. 
medRxiv preprint doi: https://doi.org/10.1101/2021.12.29.21268235; this version posted January 1, 2022. The copyright holder for this preprint (which was not certified by peer review) is the author/funder, who has granted medRxiv a license to display the preprint in It is made available under a CC-BY-NC-ND 4.0 International license .

Conclusions: Having a VB-affected pregnancy ending in a delivery was not associated with an increased women's risk of cancer in comparison with having a VB-unaffected pregnancy ending in a delivery, termination or miscarriage. 
medRxiv preprint doi: https://doi.org/10.1101/2021.12.29.21268235; this version posted January 1, 2022. The copyright holder for this preprint (which was not certified by peer review) is the author/funder, who has granted medRxiv a license to display the preprint in It is made available under a CC-BY-NC-ND 4.0 International license .

\section{WHAT IS ALREADY KNOWN ON THIS TOPIC}

- The risk of breast, endometrial, and ovarian cancer is reduced in women with childbirths.

- The risk reduction for breast, endometrial, and ovarian cancer is also observed following pregnancies ending in a termination or miscarriage, suggesting a protective association with gestation irrespective of its outcome.

\section{WHAT THIS STUDY ADDS}

- When compared with vaginal bleeding-unaffected deliveries, affected deliveries were not associated with the increased risk of any cancer and specifically of breast, cervical, ovarian and fallopian tube, and uterine cancer during the follow-up of up to 24 years.

- In comparison with pregnancies ending in a termination or miscarriage, pregnancies affected by vaginal bleeding were also not associated with subsequent risk of cancer. 
medRxiv preprint doi: https://doi.org/10.1101/2021.12.29.21268235; this version posted January 1 , 2022. The copyright holder for this preprint (which was not certified by peer review) is the author/funder, who has granted medRxiv a license to display the preprint in It is made available under a CC-BY-NC-ND 4.0 International license.

\section{INTRODUCTION}

A full-term pregnancy is associated with a $40 \%$ reduction in risks of breast, endometrial, and ovarian cancer.[1,2] A pregnancy irrespective of outcome is associated with a reduction in risks of endometrial, breast, and ovarian cancers.[1,3,4] However, pregnancy ending in a miscarriage is associated with a less pronounced protective effect against cancer of 10\%.[4] Gestation is sustained with progesterone that may play a protective role for hormone-related cancers, such as endometrial and breast cancer. $[3,4]$ Threatened and completed miscarriage share several biologic mechanisms, including increased levels of pro-inflammatory cytokines[5-7] and decreased levels of progesterone.[8,9] Threatened miscarriage affects up to $30 \%[10-14]$ of pregnancies and manifests as vaginal bleeding (VB), often during the first trimester.[10,11,15] About $30-50 \%[8,16,17]$ of VB-affected deliveries end in a miscarriage.[18-20]

The long-term risk of cancer in women with a pregnancy complicated by vaginal bleeding within 20 gestational weeks is unknown. A previous Danish study showed that VB in pregnancy is not a marker of occult cancer.[21] In this registry-based cohort study in Denmark, we investigated an association of VB-affected deliveries with the subsequent risk of cancer as compared with VB-unaffected deliveries and pregnancies ending in a termination or miscarriage.

\section{METHODS}

\section{Setting, design and data sources}

This was a registry-based cohort study conducted using patient-level linked data from Danish health and administrative registries,[22] set within Denmark's universal and tax-funded health care system. The Civil Registration System[22,23] assigns personal identifiers and contains data on date of birth, vital and civil status, dates of immigration and emigration. Data on all deliveries are captured by the Medical Birth Registries (MBR) starting in 1973[24,25] and includes women's and pregnancy-related characteristics (women's age at delivery, gestational age, parity). Smoking status in pregnancy is 
medRxiv preprint doi: https://doi.org/10.1101/2021.12.29.21268235; this version posted January 1,2022 . The copyright holder for this preprint (which was not certified by peer review) is the author/funder, who has granted medRxiv a license to display the preprint in It is made available under a CC-BY-NC-ND 4.0 International license .

collected by the MBR from 1991 and body-mass index (BMI) from 2004. Information on stillbirths at the gestational age of at least 28 full weeks is available in the MBR before April 2004 and at 22 full gestational weeks afterwards; livebirths are recorded regardless of gestational age. Information on highest education level,[26] employment status[27] and personal income[28] are stored at Statistics Denmark and available starting in 1980.[29] Hospital encounters are recorded in the Danish National Patient Registry (DNPR),[30,31] including data on medical procedures and discharge diagnoses, coded using the International Classification of Diseases, $8^{\text {th }}$ revision (ICD-8) in 1977-1993 and $10^{\text {th }}$ revision (ICD-10) thereafter.[30] Hospital admissions are available in the DNPR from 1977, while outpatient clinic and emergency room visits are recorded from 1995 onwards.[30,31] Admissions and outpatient specialist visits due to psychiatric conditions are captured by the Psychiatric Central Research Register[32] and were available in this study from 1995. The Danish National Prescription Registry[33] captures data on prescribed medication dispensings from 1995 onwards and records the Anatomical Therapeutic Classification (ATC) codes of the dispensed drugs and the dates when the prescriptions were redeemed. The Danish Cancer Registry (DCR)[34] captures all primary incident cancer diagnoses and contains data on tumours' morphology.

\section{Pregnancies affected by vaginal bleeding within $\mathbf{2 0}$ weeks of gestation and ending in delivery}

Using the MBR, we identified all deliveries between 1995 and 2017. We kept one record per delivery of a multifetal pregnancy. Using the DNPR, we obtained data on VB within 20 gestational weeks starting from the last menstrual period date, computed by subtracting gestational age at delivery from the delivery date (Table S1 in the Supplemental materials). When several VB episodes were recorded during the same gestation, we included the earliest. The index date for the affected pregnancies was the date of the hospital-based encounter due to a VB during the first 20 gestational weeks. 
medRxiv preprint doi: https://doi.org/10.1101/2021.12.29.21268235; this version posted January 1 , 2022. The copyright holder for this

preprint (which was not certified by peer review) is the author/funder, who has granted medRxiv a license to display the preprint in It is made available under a CC-BY-NC-ND 4.0 International license .

\section{Pregnancies ending in delivery unaffected by vaginal bleeding and pregnancies ending in a termination or miscarriage}

Pregnancies ending in delivery without a VB diagnosis in the DNPR during 20 weeks of gestation were classified as VB-unaffected. The index date for VB-unaffected deliveries was the date of delivery. Using the DNPR, we identified pregnancies ending in a miscarriage (spontaneous abortion) or a termination (medical or surgical abortion) in 1995-2017, using all recorded diagnoses. To identify pregnancy terminations, we also used procedure codes from the DNPR (Table S1 in the Supplemental materials). To limit the inclusion of multiple records of the same pregnancy registered in connection with hospital visits due to an earlier termination, a woman with the same diagnostic or procedure code for pregnancy termination was allowed to re-enter the cohort after 180 days, whereupon this was considered a different pregnancy. The same approach using diagnostic codes only was applied to define miscarriages. When multiple dates were available for each pregnancy termination or miscarriage episode, we included the earliest and it served as the index date. Our approach could potentially miss recurrent miscarriages within 180 days of each other. Finally, we excluded the pregnancies of women with the history of any cancer or HIV/AIDs diagnosis (Table S1 in the Supplemental materials).

\section{Cancer outcomes}

Using the DCR, we ascertained incident diagnoses of cancer. We investigated the long-term risk of any cancer; haematological, immune-related, alcohol and smoking-related, obesity-related cancers $[35,36]$ and cancers at multiple specific sites, focusing specifically on breast, cervical, ovarian and fallopian tube, and uterine cancer (Table S1 in the Supplemental materials).

\section{Covariables}

The potential confounding factors were age, calendar year of pregnancy end, women's parity, socioeconomic factors (education, employment, and year-specific income level divided into quartiles), reproductive history (previous episodes of $\mathrm{VB}$, at least one pregnancy termination or 
medRxiv preprint doi: https://doi.org/10.1101/2021.12.29.21268235; this version posted January 1,2022 . The copyright holder for this preprint (which was not certified by peer review) is the author/funder, who has granted medRxiv a license to display the preprint in It is made available under a CC-BY-NC-ND 4.0 International license .

miscarriage), and chronic somatic and psychiatric conditions (Figure S1 in the Supplemental materials). We additionally ascertained and adjusted for women's medication use before the index date as a measure of underlying health and healthcare utilization.

\section{Statistical analyses}

We followed women from the index date until the earliest of cancer diagnosis, death, emigration, or end of the study on 31 December 2017. Women with multiple cancers diagnosed at different dates were followed until the earliest of the diagnosed cancers. We computed the cumulative incidence of any cancer and haematological, immune-related, alcohol and smoking-related cancers at the end of 24-year follow-up while treating deaths and emigrations as competing events. We additionally reported the cumulative incidence of any cancer by women's age category. We computed crude incidence rates (IRs) per 10,000 person-years (PYs) of breast, cervical, ovarian and fallopian tube, uterine cancer and other cancers at specific sites as well as the incidence rate of any cancer by follow-up duration. We used Cox proportional hazards regression to compute crude and adjusted hazard ratios (HRs) for all investigated cancer outcomes. We computed 95\% confidence intervals (Cls) using a robust standard error when different pregnancies of the same woman were analysed. In three separate sets of analyses, we compared the risk of cancer outcomes for VB-affected deliveries with that of VB-unaffected deliveries and pregnancies ending in a termination or miscarriage. For any cancer and haematological, immune-related, alcohol and smoking-related, and obesity-related cancers, we computed HRs adjusted for potential confounders (women's history of previous terminations, miscarriages, and VB episodes; history of thyroid conditions, obesity, chronic liver and kidney diseases, medication use as a proxy of women's overall health) using multivariable proportional hazards Cox regression. For these cancer outcomes, we additionally computed HRs using the average effect in the treated (ATT) weighting (the formula is available in the Supplemental materials). We performed truncation at the $1^{\text {st }}$ and $99^{\text {th }}$ percentile of the ATT weights distribution. $[37,38]$ Further, we computed the risks of any cancer and cancers at specific sites 
medRxiv preprint doi: https://doi.org/10.1101/2021.12.29.21268235; this version posted January 1 , 2022. The copyright holder for this preprint (which was not certified by peer review) is the author/funder, who has granted medRxiv a license to display the preprint in It is made available under a CC-BY-NC-ND 4.0 International license .

following women's first pregnancies. In a sensitivity analysis, we investigated the risk of any cancer and haematological, immune-related, alcohol and smoking-related, and obesity-related cancers additionally adjusted for women's BMI in pregnancy; however, the follow-up was short and accrued few events. We additionally investigated the risk of cancer restricting the data to women having their last recorded pregnancy at the age of 40 years or later.

Using log-minus-log plots, we visually evaluated the proportionality of hazards assumptions for all Cox proportional hazards analyses and the curves were close to parallel over the entire follow-up period. All analyses were conducted at Statistics Denmark[29] using RStudio[39] and R[40] versions 3.6.0-4.1.0 including the following packages and their dependencies: tidyverse,[41] ggplot2,[42] survival,[43] cmprsk,[44] prodlim,[45] epiR[46]. Reported counts were clouded whenever appropriate to protect personal data.

\section{Ethics}

No patient consent or ethical approval is required for registry-based research according to Danish legislation. This study was reported to the Danish Data Protection Agency[47] through registration at Aarhus University (record number: AU-2016-051-000001, sequential number 605).

\section{RESULTS}

\section{Descriptive characteristics}

This study included 37,085 VB-affected deliveries among 35,517 women; 1,362,760 VB-unaffected deliveries among 783,020 women; 324,395 terminations among 239,729 women and 137,040 miscarriages among 121,303 women in 1995-2017 (Figure 1). Women's age, parity, civil status, employment, income, obesity, chronic pulmonary, liver and kidney conditions, alcohol abuse, and medication use had similar distributions for VB-affected and VB-unaffected deliveries. Of women with VB-affected vs VB-unaffected deliveries, $29.0 \%$ vs $35.0 \%$ had higher education, $13.0 \%$ vs $4.9 \%$ had a previous record of VB diagnosis irrespective of pregnancy outcome, $6.2 \%$ vs $2.1 \%$ had a history 
medRxiv preprint doi: https://doi.org/10.1101/2021.12.29.21268235; this version posted January 1,2022 . The copyright holder for this preprint (which was not certified by peer review) is the author/funder, who has granted medRxiv a license to display the preprint in It is made available under a CC-BY-NC-ND 4.0 International license .

of a previous VB episode within 20 gestational weeks of a pregnancy ending in a delivery, $22.0 \%$ vs $12.0 \%$ had at least one previous miscarriage; $19.0 \%$ vs $15.0 \%$ were smokers (Table 1 ).

Pregnancies ending in a termination were more likely to be of younger ( $<24$ years), unmarried, nulliparous and unemployed women, who had a lower level of the highest attained education and were in the first income quartile compared with pregnancies ending in a delivery or miscarriage (Table 1). Pregnancies ending in a miscarriage were more likely than VB-affected deliveries to be of women older than 35 years and $15.0 \%$ had a previous miscarriage (Table 1 ).

\section{Cumulative incidences and incidence rates of the cancer outcomes}

During the follow-up of up to 24 years, there were 1,725 cancer events following VB-affected deliveries, 52,620 events following VB-unaffected deliveries, 12,925 events following a termination and 6,080 events following a miscarriage (Table 2). At the end of the follow-up, the cumulative incidence of any cancer was $9.9 \%$ for pregnancies ending in a delivery irrespective of whether or not they were complicated by VB. The cumulative incidence of any cancer following pregnancies ending in a termination or miscarriage was 9.3\% (95\% Cl: 9.1\%-9.6\%) and 10.3\% (95\% Cl: 9.9\%-10.8\%), respectively (Table 2). The highest cumulative incidence of any cancer was observed for women of $40+$ years at pregnancy end (Figure S2 in the Supplemental materials). The cumulative incidence of haematological, immune-related, smoking and alcohol-related, and obesity-related cancers was similar for VB-affected and VB-unaffected deliveries as well as pregnancies ending in a termination or miscarriage (Table 2, Figure S3 in the Supplemental materials).

The incidence rate of any cancer was 32.1 (95\% Cl: 30.6-33.6) per 10,000 PYs for VB-affected deliveries and 31.5 (95\% Cl: 31.2-31.7) per 10,000 PYs for VB-affected deliveries (Table 2). The incidence rate of any cancer was slightly higher during the first 5 years of follow-up for every pregnancy cohort than during later follow-up periods (Table S2 in the Supplemental materials). The incidence rates of smoking and alcohol-related cancers and obesity-related cancers were slightly higher for VB-affected (1.6, 95\% Cl: 1.3-2.0 and 11.3, 95\% Cl: 11.4-11.7 per 10,000 PYs, respectively) vs VB-unaffected deliveries (1.5, 95\% Cl: 1.4-1.6 and 11.1, 95\% Cl: 10.9-11.3 per 10,000 PYs, 
medRxiv preprint doi: https://doi.org/10.1101/2021.12.29.21268235; this version posted January 1,2022 . The copyright holder for this preprint (which was not certified by peer review) is the author/funder, who has granted medRxiv a license to display the preprint in It is made available under a CC-BY-NC-ND 4.0 International license .

respectively) (Table 2). The incidence rates of breast, cervical, ovary and fallopian tube, uterine cancer, and cancers at other sites were similar for all ascertained cohorts of pregnancies (Table 2, Table S3 in the Supplemental materials).

\section{Hazard ratios for the cancer outcomes}

In the ATT-weighting adjusted analysis, the HR for any cancer among vaginal-bleeding affected deliveries was 0.98 (95\% Cl: 0.93-1.03) compared with VB-unaffected, 1.00 (95\% Cl: 0.94-1.06) compared with terminations, and 1.04 (95\% Cl: 0.94-1.14) compared with miscarriages. The conventionally adjusted models yielded nearly identical results, which remained unchanged in the subcohort of first pregnancies (Table 3).

There was no association between VB-affected pregnancy and subsequent risk of haematological, immune-related, obesity-related or other cancers across all comparators (Table 4, Table S4 in the Supplemental materials). When contrasting the risk of smoking and alcohol-related cancers following all VB-affected vs all VB-unaffected deliveries the HR was 0.92 (95\% Cl: $0.74-1.14)$. We observed a $38 \%$ increased hazard of smoking and alcohol-related cancers following first-recorded pregnancies ( $\mathrm{HR}=1.38,95 \% \mathrm{Cl}: 0.93-2.04$ ), although the confidence interval was wide (Table 4, Table S4 in the Supplemental materials). There was a protective association for VB-affected deliveries with smoking and alcohol-related cancers when compared with pregnancies ending in a termination $(\mathrm{HR}=0.77,95 \% \mathrm{Cl}: 0.60-0.98)$ or miscarriage $(\mathrm{HR}=0.64,95 \% \mathrm{Cl}: 0.47-0.88)$. However, the latter associations could not be adjusted for women's smoking status and BMI, since this information was only available for pregnancies ending in a delivery.

As compared with VB-unaffected deliveries, there was no increase in relative risk of breast $(H R=0.94$, $95 \% \mathrm{Cl}: 0.86-1.03)$, cervical $(0.94,0.77-1.14)$, ovarian and fallopian tube $(1.16,0.81-1.66)$, and uterine cancer $(0.78,0.46-1.33)$ following VB-unaffected deliveries (Table 5). Similarly, we found no association with other investigated site-specific cancers across comparisons with VB-unaffected deliveries and pregnancies ending in a termination or miscarriage (Table S5 in the Supplemental materials). 
medRxiv preprint doi: https://doi.org/10.1101/2021.12.29.21268235; this version posted January 1,2022 . The copyright holder for this

preprint (which was not certified by peer review) is the author/funder, who has granted medRxiv a license to display the preprint in It is made available under a CC-BY-NC-ND 4.0 International license .

Sensitivity analysis of pregnancies ending in delivery from 2004 onwards with additional adjustment for woman's BMI in pregnancy showed results consistent with the findings from the main analyses, however, some HRs for cancers at specific sites were inestimable due to short follow-up and few events (Table S6 in the Supplemental materials).

\section{DISCUSSION}

\section{Principal findings}

In this registry-based cohort study, we found no evidence of an association between VB in pregnancy carried to delivery and subsequent risk of cancer over the 24-year follow-up. When compared with VB-unaffected deliveries, there was no increased risk of any cancer and specifically breast, cervical, ovarian and fallopian tube, and uterine cancer in women. Similarly, we found no associations with any cancer and site-specific cancers in women when contrasting VB-affected deliveries with pregnancies ending in a termination or miscarriage.

\section{Comparison with other studies}

No other studies investigated an association of VB within 20 gestational weeks of pregnancy ending in delivery and subsequent risk of any cancer and cancers at multiple specific sites as compared with VB-unaffected deliveries and pregnancies ending in a termination or miscarriage. This study indirectly supports the findings of previous research on risk of breast, ovarian and endometrial cancer. These studies found that the risk was similarly reduced in women with gestation irrespective of whether the pregnancies were carried until delivery or not. $[1,3,4]$ This study is also in line with a Danish study reporting no association between VB in pregnancy and occult cancer[21].

\section{Strengths and limitations of the study}

Due to nearly complete administrative follow-up for every woman, selection bias at inclusion of pregnancies in the cohorts is negligible, but potential selection bias from unidentified early miscarriages cannot be ruled out. In the analyses, we controlled for multiple potential confounding factors. Data on proxies of the lifestyle such as smoking and BMI were available only for pregnancies 
medRxiv preprint doi: https://doi.org/10.1101/2021.12.29.21268235; this version posted January 1, 2022. The copyright holder for this preprint (which was not certified by peer review) is the author/funder, who has granted medRxiv a license to display the preprint in It is made available under a CC-BY-NC-ND 4.0 International license .

ending in deliveries starting from 2004 and unavailable for pregnancies ending in miscarriages or terminations. At the same time, we have no reason to assume that in the context of Denmark, VBaffected and VB-unaffected deliveries would be of women with very different lifestyles. Moreover, no lifestyle factor of women with VB in pregnancy is likely to dilute the associations.

Diagnoses of VB in pregnancy due to threatened miscarriage was not validated in the DNPR. The validity of similar diagnoses for miscarriage and of diagnoses and procedures for pregnancy termination in the DNPR is high (positive predictive value $>90 \%$ ). $[30,48]$ We could potentially miss recurrent miscarriages within 180 days of each other. However, owing to high specificity of miscarriage diagnoses and few false-positives, the misclassification of miscarriages is not a major concern. A diagnostic work-up for threatened miscarriage includes an ultrasound for establishing pregnancy viability, foetal heartbeat, and to eliminate other causes of VB such as ectopic pregnancy. $[10,49]$ The prevalence of VB in this study is low $(<3 \%)$ compared with estimates reported elsewhere (up to 30\%)[10-14]. We argue that identified VB diagnoses in this study had high specificity, however, a large proportion of VB may be missed. This may cause bias only if captured episodes of VB systematically differ from all such episodes.

Owing to compulsory reporting of incident primary tumours, the accuracy of cancer diagnoses in the DCR and its coverage is very high, with nearly $90 \%$ of tumours having a morphological verification.[34] Thus, misclassification of the outcome is unlikely in this study and cannot explain the null findings.

\section{CONCLUSION}

We found no evidence of an association between VB in pregnancy and subsequent long-term risk of cancer. 
medRxiv preprint doi: https://doi.org/10.1101/2021.12.29.21268235; this version posted January 1, 2022. The copyright holder for this preprint (which was not certified by peer review) is the author/funder, who has granted medRxiv a license to display the preprint in It is made available under a CC-BY-NC-ND 4.0 International license.

Contributors: ED, EHP, HTS, VE designed the study. HTS facilitated the data application. ED prepared the statistical analysis plan and conducted statistical analyses. EHP provided expertise and supervision of the statistical analyses. All authors participated in the discussion of the results and their interpretation. ED drafted the manuscript, organised the writing, and produced a graphical presentation of the results. HTS provided clinical expertise. All authors equally participated in the critical revision of the manuscript and approved its final version. HTS is the guarantor.

Funding: Department of Clinical Epidemiology, Aarhus University partaking in studies with institutional funding from regulators and pharmaceutical companies, given as research grants to and administered by Aarhus University. None of these projects is related to the current study.

Competing interests: All authors report no competing interest.

Ethics approval: Not required for registry-based research in Denmark.

Data sharing: Data is not available for sharing to protect the identity of participants according to Danish legislation.

Patient and public involvement: Patients or the public were not involved in the design, or conduct, or reporting, or dissemination of this research. 
medRxiv preprint doi: https://doi.org/10.1101/2021.12.29.21268235; this version posted January $1,2022$. The copyright holder for this preprint (which was not certified by peer review) is the author/funder, who has granted medRxiv a license to display the preprint in It is made available under a CC-BY-NC-ND 4.0 International license.

\section{References:}

1 Jordan SJ, Na R, Weiderpass E, et al. Pregnancy outcomes and risk of endometrial cancer: A pooled analysis of individual participant data in the Epidemiology of Endometrial Cancer Consortium. International Journal of Cancer 2021;148:2068-78. doi:10.1002/ijc.33360

$2 \mathrm{Ma} \mathrm{H}$, Bernstein L, Pike MC, et al. Reproductive factors and breast cancer risk according to joint estrogen and progesterone receptor status: a meta-analysis of epidemiological studies. Breast cancer research : BCR 2006;8:R43. doi:10.1186/bcr1525

3 Husby A, Wohlfahrt J, Øyen N, et al. Pregnancy duration and breast cancer risk. Nat Commun 2018;9:4255. doi:10.1038/s41467-018-06748-3

4 Husby A, Wohlfahrt J, Melbye M. Pregnancy duration and endometrial cancer risk: nationwide cohort study. BMJ 2019;366:14693. doi:10.1136/bmj.14693

5 Alijotas-Reig J, Llurba E, Gris JM. Potentiating maternal immune tolerance in pregnancy: a new challenging role for regulatory T cells. Placenta 2014;35:241-8.

doi:10.1016/j.placenta.2014.02.004

6 Calleja-Agius J, Schembri-Wismayer P, Calleja N, et al. Obstetric outcome and cytokine levels in threatened miscarriage. Gynecol Endocrinol 2011;27:121-7.

doi:10.3109/09513590.2010.487614

7 Alijotas-Reig J, Esteve-Valverde E, Ferrer-Oliveras R, et al. Tumor Necrosis Factor-Alpha and Pregnancy: Focus on Biologics. An Updated and Comprehensive Review. Clin Rev Allergy Immunol 2017;53:40-53. doi:10.1007/s12016-016-8596-x

8 Coomarasamy A, Gallos ID, Papadopoulou A, et al. Sporadic miscarriage: evidence to provide effective care. The Lancet 2021;397:1668-74. doi:10.1016/S0140-6736(21)00683-8

9 Lek SM, Ku CW, Allen JC, et al. Validation of serum progesterone $<35 \mathrm{nmol} / \mathrm{L}$ as a predictor of miscarriage among women with threatened miscarriage. BMC Pregnancy Childbirth 2017;17:78. doi:10.1186/s12884-017-1261-4

10 Axelsen SM, Henriksen TB, Hedegaard M, et al. Characteristics of vaginal bleeding during pregnancy. European Journal of Obstetrics \& Gynecology and Reproductive Biology 1995;63:131-4. doi:10.1016/0301-2115(95)02236-8

11 Smits LM, North RA, Kenny LC, et al. Patterns of vaginal bleeding during the first 20 weeks of pregnancy and risk of pre-eclampsia in nulliparous women: results from the SCOPE study. Acta Obstetricia et Gynecologica Scandinavica 2012;91:1331-8. doi:10.1111/j.1600-

0412.2012.01496.x

12 Strobino B, Pantel-Silverman J. Gestational vaginal bleeding and pregnancy outcome. American Journal of Epidemiology 1989;129:806-15. doi:10.1093/oxfordjournals.aje.a115195

13 Wijesiriwardana A, Bhattacharya S, Shetty A, et al. Obstetric Outcome in Women With Threatened Miscarriage in the First Trimester. Obstetrics \& Gynecology 2006;107:557-62. doi:10.1097/01.AOG.0000199952.82151.de 
medRxiv preprint doi: https://doi.org/10.1101/2021.12.29.21268235; this version posted January $1,2022$. The copyright holder for this preprint (which was not certified by peer review) is the author/funder, who has granted medRxiv a license to display the preprint in It is made available under a CC-BY-NC-ND 4.0 International license .

14 Saraswat L, Bhattacharya S, Maheshwari A, et al. Maternal and perinatal outcome in women with threatened miscarriage in the first trimester: a systematic review. BJOG 2010;117:245-57. doi:10.1111/j.1471-0528.2009.02427.x

15 DeVilbiss EA, Naimi Al, Mumford SL, et al. Vaginal bleeding and nausea in early pregnancy as predictors of clinical pregnancy loss. American Journal of Obstetrics and Gynecology 2020;223:570.e1-570.e14. doi:10.1016/j.ajog.2020.04.002

16 Sapra KJ, Joseph KS, Galea S, et al. Signs and Symptoms of Early Pregnancy Loss. Reprod Sci 2017;24:502-13. doi:10.1177/1933719116654994

17 Mouri M, Hall H, Rupp TJ. Threatened Abortion. 2017. http://europepmc.org/article/NBK/NBK430747 (accessed 6 Apr 2021).

18 Coomarasamy A, Devall AJ, Cheed V, et al. A Randomized Trial of Progesterone in Women with Bleeding in Early Pregnancy. New England Journal of Medicine 2019;380:1815-24. doi:10.1056/NEJMoa1813730

19 Ogwulu CO, Goranitis I, Devall AJ, et al. The cost-effectiveness of progesterone in preventing miscarriages in women with early pregnancy bleeding: an economic evaluation based on the PRISM trial. BJOG: An International Journal of Obstetrics \& Gynaecology 2020;127:757-67. doi:https://doi.org/10.1111/1471-0528.16068

20 Quenby S, Gallos ID, Dhillon-Smith RK, et al. Miscarriage matters: the epidemiological, physical, psychological, and economic costs of early pregnancy loss. The Lancet 2021;397:1658-67. doi:10.1016/S0140-6736(21)00682-6

21 Dudukina E, Farkas DK, Horváth-Puhó E, et al. Vaginal bleeding in early pregnancy and risk of occult cancer. International Journal of Gynecology \& Obstetrics 2019;146:387-9. doi:10.1002/ijgo.12867

22 Schmidt M, Pedersen L, Sorensen HT. The Danish Civil Registration System as a tool in epidemiology. Eur J Epidemiol 2014;29:541-9. doi:10.1007/s10654-014-9930-3

23 Pedersen CB. The Danish Civil Registration System. Scandinavian Journal of Public Health 2011;39:22-5. doi:10.1177/1403494810387965

24 Knudsen LB, Olsen J. The Danish Medical Birth Registry. Danish medical bulletin 1998;45:320-3.

25 Bliddal M, Broe A, Pottegard A, et al. The Danish Medical Birth Register. Eur J Epidemiol 2018;33:27-36. doi:10.1007/s10654-018-0356-1

26 Jensen VM, Rasmussen AW. Danish Education Registers. Scand J Public Health 2011;39:91-4. doi:10.1177/1403494810394715

27 Petersson F, Baadsgaard M, Thygesen LC. Danish registers on personal labour market affiliation. Scand J Public Health 2011;39:95-8. doi:10.1177/1403494811408483

28 Baadsgaard M, Quitzau J. Danish registers on personal income and transfer payments. Scand J Public Health 2011;39:103-5. doi:10.1177/1403494811405098

29 Statistics Denmark. 2021.https://www.dst.dk/en (accessed 30 Jun 2021). 
medRxiv preprint doi: https://doi.org/10.1101/2021.12.29.21268235; this version posted January $1,2022$. The copyright holder for this preprint (which was not certified by peer review) is the author/funder, who has granted medRxiv a license to display the preprint in It is made available under a CC-BY-NC-ND 4.0 International license.

30 Schmidt M, Schmidt SA, Sandegaard JL, et al. The Danish National Patient Registry: a review of content, data quality, and research potential. Clin Epidemiol 2015;7:449-90.

doi:10.2147/CLEP.S91125

31 Laugesen K, Ludvigsson JF, Schmidt M, et al. Nordic Health Registry-Based Research: A Review of Health Care Systems and Key Registries. CLEP 2021;13:533-54. doi:10.2147/CLEP.S314959

32 Mors O, Perto GP, Mortensen PB. The Danish Psychiatric Central Research Register. Scand J Public Health 2011;39:54-7. doi:10.1177/1403494810395825

33 Pottegard A, Schmidt SAJ, Wallach-Kildemoes H, et al. Data Resource Profile: The Danish National Prescription Registry. Int J Epidemiol 2017;46:798-798f. doi:10.1093/ije/dyw213

34 Gjerstorff ML. The Danish Cancer Registry. Scand J Public Health 2011;39:42-5. doi:10.1177/1403494810393562

35 Ording AG, Veres K, Farkas DK, et al. Risk of cancer in patients with epistaxis and haemoptysis. Br J Cancer 2018;118:913-9. doi:10.1038/bjc.2017.494

36 Gribsholt SB, Cronin-Fenton D, Veres K, et al. Hospital-diagnosed overweight and obesity related to cancer risk: a 40-year Danish cohort study. Journal of Internal Medicine 2020;287:435-47. doi:10.1111/joim.13013

37 Cole SR, Hernan MA. Constructing inverse probability weights for marginal structural models. Am J Epidemiol 2008;168:656-64. doi:10.1093/aje/kwn164

38 Austin PC, Stuart EA. Moving towards best practice when using inverse probability of treatment weighting (IPTW) using the propensity score to estimate causal treatment effects in observational studies. Stat Med 2015;34:3661-79. doi:10.1002/sim.6607

39 RStudio Team. RStudio: Integrated Development for R. Boston, MA: : RStudio, PBC 2020. http://www.rstudio.com/

40 R Core Team. R: A language and environment for statistical computing. Vienna, Austria: 2013. http://www.R-project.org/

41 Wickham H, Averick M, Bryan J, et al. Welcome to the Tidyverse. Journal of Open Source Software 2019;4:1686. doi:10.21105/joss.01686

42 Wickham H. ggplot2: Elegant Graphics for Data Analysis:Elegant Graphics for Data Analysis. Springer-Verlag New York 2016. https://ggplot2.tidyverse.org

43 Therneau TM, Thomas L, Elizabeth A, et al. survival: Survival Analysis. 2021. https://CRAN.Rproject.org/package=survival (accessed 6 Apr 2021).

44 Gray B. cmprsk: Subdistribution Analysis of Competing Risks. 2020. https://CRAN.Rproject.org/package $=$ cmprsk (accessed 31 Mar 2021).

45 Gerds TA. prodlim: Product-Limit Estimation for Censored Event History Analysis. 2019. https://CRAN.R-project.org/package=prodlim (accessed 31 Mar 2021). 
medRxiv preprint doi: https://doi.org/10.1101/2021.12.29.21268235; this version posted January 1, 2022. The copyright holder for this preprint (which was not certified by peer review) is the author/funder, who has granted medRxiv a license to display the preprint in It is made available under a CC-BY-NC-ND 4.0 International license .

46 Nunes MS and ES with contributions from T, Heuer C, Marshall J, et al. epiR: Tools for the Analysis of Epidemiological Data. 2021. https://CRAN.R-project.org/package=epiR (accessed 29 Jul 2021).

47 Datatilsynet. Datatilsynet/The Danish Data Protection Agency. Datatilsynet/The Danish Data Protection Agency. http://www.datatilsynet.dk/english (accessed 16 Sep 2020).

48 Lohse SR, Farkas DK, Lohse N, et al. Validation of spontaneous abortion diagnoses in the Danish National Registry of Patients. Clin Epidemiol 2010;2:247-50. doi:10.2147/CLEP.S13815

49 Norwitz ER, Park JS, Lockwood CJ, et al. Overview of the etiology and evaluation of vaginal bleeding in pregnancy - UpToDate. 2021.https://www.uptodate.com/contents/overview-of-theetiology-and-evaluation-of-vaginal-bleeding-in-pregnancy (accessed 30 Aug 2021). 
medRxiv preprint doi: https://doi.org/10.1101/2021.12.29.21268235; this version posted January $1,2022$. The copyright holder for this preprint (which was not certified by peer review) is the author/funder, who has granted medRxiv a license to display the preprint in It is made available under a CC-BY-NC-ND 4.0 International license .

Figure 1. Flow chart for the pregnancy cohorts' ascertainment

Table 1. Descriptive characteristics of vaginal bleeding-affected deliveries, vaginal bleedingunaffected deliveries, pregnancies ending in a termination or miscarriage, Denmark, 1995-2017

\begin{tabular}{|c|c|c|c|c|c|c|c|c|}
\hline \multirow[t]{2}{*}{ Characteristic } & \multicolumn{2}{|c|}{$\begin{array}{l}\text { VB-affected } \\
\text { deliveries, } \\
N=37,085 \\
\text { (35,517 women) }\end{array}$} & \multicolumn{2}{|c|}{$\begin{array}{l}\text { VB-unaffected } \\
\text { deliveries, } \\
N=1,362,760 \\
\text { (783,020 women) }\end{array}$} & \multicolumn{2}{|c|}{$\begin{array}{l}\text { Terminations, } \\
\mathrm{N}=324,395 \\
(239,729 \text { women })\end{array}$} & \multicolumn{2}{|c|}{$\begin{array}{l}\text { Miscarriages, } \\
N=137,040 \\
\text { (121,303 women) }\end{array}$} \\
\hline & $\mathbf{N}$ & $\%$ & $\mathbf{N}$ & $\%$ & $\mathbf{N}$ & $\%$ & $\mathbf{N}$ & $\%$ \\
\hline \multicolumn{9}{|c|}{ Age at pregnancy, years } \\
\hline$<20$ & 565 & 1.5 & 20,015 & 1.5 & 46,220 & 14.0 & 4,635 & 3.4 \\
\hline $20-24$ & 5,035 & 14.0 & 163,915 & 12.0 & 74,415 & 23.0 & 17,415 & 13.0 \\
\hline $25-29$ & 12,270 & 33.0 & 464,200 & 34.0 & 68,090 & 21.0 & 37,455 & 27.0 \\
\hline $30-34$ & 12,375 & 33.0 & 476,165 & 35.0 & 65,405 & 20.0 & 39,795 & 29.0 \\
\hline $35-39$ & 5,715 & 15.0 & 202,300 & 15.0 & 49,440 & 15.0 & 26,135 & 19.0 \\
\hline $40+$ & 1,125 & 3.0 & 36,165 & 2.7 & 20,655 & 6.4 & 11,535 & 8.4 \\
\hline missing ${ }^{a}$ & 0 & 0.0 & 0 & 0.0 & 170 & 0.1 & 70 & 0.1 \\
\hline \multicolumn{9}{|c|}{ Calendar year of pregnancy } \\
\hline 1995-1999 & 12,660 & 34.0 & 308,280 & 23.0 & 88,975 & 27.0 & 33,555 & 24.0 \\
\hline $2000-2004$ & 8,265 & 22.0 & 243,000 & 18.0 & 63,425 & 20.0 & 25,460 & 19.0 \\
\hline $2005-2008$ & 7,220 & 19.0 & 304,200 & 22.0 & 72,315 & 22.0 & 33,855 & 25.0 \\
\hline $2009-2013$ & 4,730 & 13.0 & 228,775 & 17.0 & 50,595 & 16.0 & 25,345 & 18.0 \\
\hline $2013-2017$ & 4,205 & 11.0 & 278,500 & 20.0 & 49,080 & 15.0 & 18,820 & 14.0 \\
\hline \multicolumn{9}{|c|}{ Smoking in pregnancy } \\
\hline Smoker & 6,995 & 19.0 & 209,830 & 15.0 & N/A & $\mathrm{N} / \mathrm{A}$ & $\mathrm{N} / \mathrm{A}$ & $\mathrm{N} / \mathrm{A}$ \\
\hline Non-smoker & 26,205 & 71.0 & $1,048,830$ & 77.0 & N/A & $\mathrm{N} / \mathrm{A}$ & $N / A$ & $\mathrm{~N} / \mathrm{A}$ \\
\hline Missing & 3,885 & 10.0 & 104,095 & 7.6 & N/A & $\mathrm{N} / \mathrm{A}$ & $\mathrm{N} / \mathrm{A}$ & $\mathrm{N} / \mathrm{A}$ \\
\hline \multicolumn{9}{|c|}{ Parity at the index or at the delivery date } \\
\hline Nulliparous & 0 & 0.0 & 0 & 0.0 & 205,465 & 63.0 & 110,445 & 81.0 \\
\hline Primiparous & 17,105 & 46.0 & 628,845 & 46.0 & 32,750 & 10.0 & 10,870 & 7.9 \\
\hline Multiparous & 19,980 & 54.0 & 733,910 & 54.0 & 86,180 & 27.0 & 15,725 & 11.0 \\
\hline \multicolumn{9}{|c|}{ Pregnancy number at the index date } \\
\hline 1 & 11,795 & 32.0 & 512,325 & 38.0 & 112,430 & 35.0 & 43,950 & 32.0 \\
\hline 2 & 11,140 & 30.0 & 447,200 & 33.0 & 59,720 & 18.0 & 39,880 & 29.0 \\
\hline $3+$ & 14,150 & 38.0 & 403,230 & 30.0 & 152,245 & 47.0 & 53,210 & 39.0 \\
\hline \multicolumn{9}{|c|}{ BMI category, $\mathrm{kg} / \mathrm{m}^{2}, 2004-2017$} \\
\hline$<18.49$ & 905 & 2.4 & 35,280 & 2.6 & $\mathrm{~N} / \mathrm{A}$ & N/A & N/A & N/A \\
\hline $18.5-24.99$ & 10,080 & 27.0 & 484,830 & 36.0 & N/A & N/A & N/A & N/A \\
\hline $25.0-29.99$ & 3,285 & 8.9 & 165,200 & 12.0 & N/A & N/A & N/A & N/A \\
\hline $30.0+$ & 2,220 & 6.0 & 97,555 & 7.2 & $\mathrm{~N} / \mathrm{A}$ & N/A & N/A & $\mathrm{N} / \mathrm{A}$ \\
\hline missing & 20,590 & 56.0 & 579,895 & 43.0 & $\mathrm{~N} / \mathrm{A}$ & N/A & $\mathrm{N} / \mathrm{A}$ & $\mathrm{N} / \mathrm{A}$ \\
\hline \multicolumn{9}{|l|}{ Civil status } \\
\hline $\begin{array}{l}\text { Married or in } \\
\text { partnership }\end{array}$ & 21,980 & 59.0 & 819,015 & 60.0 & 103,120 & 32.0 & 67,870 & 50.0 \\
\hline Not married & 10,380 & 28.0 & 383,100 & 28.0 & 163,720 & 50.0 & 42,675 & 31.0 \\
\hline Missing & 4,720 & 13.0 & 160,640 & 12.0 & 57,550 & 18.0 & 26,495 & 19.0 \\
\hline \multicolumn{9}{|c|}{ Employment status } \\
\hline Employed & 26,965 & 73.0 & $1,017,100$ & 75.0 & 194,750 & 60.0 & 98,565 & 72.0 \\
\hline
\end{tabular}


medRxiv preprint doi: https://doi.org/10.1101/2021.12.29.21268235; this version posted January 1 , 2022. The copyright holder for this preprint (which was not certified by peer review) is the author/funder, who has granted medRxiv a license to display the preprint in It is made available under a CC-BY-NC-ND 4.0 International license .

\begin{tabular}{|c|c|c|c|c|c|c|c|c|}
\hline \multirow[t]{2}{*}{ Characteristic } & \multicolumn{2}{|c|}{$\begin{array}{l}\text { VB-affected } \\
\text { deliveries, } \\
N=37,085 \\
\text { (35,517 women) }\end{array}$} & \multicolumn{2}{|c|}{$\begin{array}{l}\text { VB-unaffected } \\
\text { deliveries, } \\
N=1,362,760 \\
\text { (783,020 women) }\end{array}$} & \multicolumn{2}{|c|}{$\begin{array}{l}\text { Terminations, } \\
N=324,395 \\
(239,729 \text { women })\end{array}$} & \multicolumn{2}{|c|}{$\begin{array}{l}\text { Miscarriages, } \\
N=137,040 \\
(121,303 \text { women })\end{array}$} \\
\hline & $\mathbf{N}$ & $\%$ & $\mathbf{N}$ & $\%$ & $\mathbf{N}$ & $\%$ & $\mathbf{N}$ & $\%$ \\
\hline $\begin{array}{l}\text { Retirement or state } \\
\text { pension }\end{array}$ & 3,400 & 9.2 & 100,585 & 7.4 & 41,220 & 13.0 & 13,025 & 9.5 \\
\hline Unemployed & 5,750 & 15.0 & 201,390 & 15.0 & 80,915 & 25.0 & 21,325 & 16.0 \\
\hline Missing & 970 & 2.6 & 43,685 & 3.2 & 7,510 & 2.3 & 4,125 & 3.0 \\
\hline \multicolumn{9}{|c|}{ Highest achieved education } \\
\hline Basic education & 9,825 & 26.0 & 272,035 & 20.0 & 145,845 & 45.0 & 35,665 & 26.0 \\
\hline High school or similar & 15,095 & 41.0 & 553,225 & 41.0 & 109,285 & 34.0 & 53,350 & 39.0 \\
\hline Higher education & 10,595 & 29.0 & 472,920 & 35.0 & 48,885 & 15.0 & 41,065 & 30.0 \\
\hline Missing & 1,565 & 4.2 & 64,575 & 4.7 & 20,375 & 6.3 & 6,955 & 5.1 \\
\hline \multicolumn{9}{|c|}{ Year-specific income, quartiles } \\
\hline Q1 & 8,905 & 24.0 & 282,170 & 21.0 & 130,565 & 40.0 & 33,140 & 24.0 \\
\hline Q2 & 9,460 & 26.0 & 326,525 & 24.0 & 82,275 & 25.0 & 34,485 & 25.0 \\
\hline Q3 & 8,880 & 24.0 & 358,770 & 26.0 & 52,535 & 16.0 & 32,670 & 24.0 \\
\hline Q4 & 9,170 & 25.0 & 361,665 & 27.0 & 47,110 & 15.0 & 33,130 & 24.0 \\
\hline missing & 675 & 1.8 & 33,625 & 2.5 & 11,905 & 3.7 & 3,620 & 2.6 \\
\hline \multicolumn{9}{|l|}{ Reproductive history } \\
\hline Previous VB diagnosis & 4,865 & 13.0 & 66,285 & 4.9 & 23,920 & 7.4 & 16,995 & 12.0 \\
\hline $\begin{array}{l}\text { Previous VB within } 20 \\
\text { gestational weeks of a } \\
\text { pregnancy ending in a } \\
\text { delivery }\end{array}$ & 2,315 & 6.2 & 29,275 & 2.1 & 11,990 & 3.7 & 5,040 & 3.7 \\
\hline $\begin{array}{l}\text { Previous pregnancy } \\
\text { termination }\end{array}$ & 8,615 & 23.0 & 224,265 & 16.0 & 110,440 & 34.0 & 30,170 & 22.0 \\
\hline \multicolumn{8}{|l|}{ Comorbidities } & 15.0 \\
\hline Obesity diagnosis & 1,590 & 4.3 & 128,030 & 9.4 & 13,350 & 4.1 & 6,775 & 4.9 \\
\hline Thyroid disorders & 780 & 2.1 & 30,895 & 2.3 & 5,100 & 1.6 & 2,985 & 2.2 \\
\hline COPD & 450 & 1.2 & 14,140 & 1.0 & 3,410 & 1.1 & 1,450 & 1.1 \\
\hline Chronic kidney disease & 105 & 0.3 & 2,775 & 0.2 & 775 & 0.2 & 305 & 0.2 \\
\hline Chronic liver disease & 85 & 0.2 & 3,400 & 0.2 & 955 & 0.3 & 385 & 0.3 \\
\hline Hyperlipidaemia & 10 & 0.1 & 375 & 0.1 & 85 & 0.1 & 50 & 0.1 \\
\hline Hypercholesterolemia & 40 & 0.1 & 1,485 & 0.1 & 355 & 0.1 & 190 & 0.1 \\
\hline Diabetes type 1 and 2 & 200 & 0.5 & 7,845 & 0.6 & 1,770 & 0.5 & 1,025 & 0.7 \\
\hline Hypertension & 205 & 0.6 & 7,725 & 0.6 & 1,705 & 0.5 & 960 & 0.7 \\
\hline $\begin{array}{l}\text { Ischaemic heart } \\
\text { disease }\end{array}$ & 55 & 0.1 & 1,440 & 0.1 & 585 & 0.2 & 275 & 0.2 \\
\hline Heart failure & 20 & 0.1 & 370 & 0.1 & 115 & 0.1 & 70 & 0.1 \\
\hline Ischaemic stroke & 55 & 0.1 & 1,255 & 0.1 & 450 & 0.1 & 195 & 0.1 \\
\hline Haemorrhagic stroke & 50 & 0.1 & 1,195 & 0.1 & 395 & 0.1 & 175 & 0.1 \\
\hline Deep vein thrombosis & 115 & 0.3 & 4,525 & 0.3 & 1,220 & 0.4 & 565 & 0.4 \\
\hline Pulmonary embolism & 65 & 0.2 & 1,910 & 0.1 & 510 & 0.2 & 245 & 0.2 \\
\hline \multicolumn{9}{|l|}{ Psychiatric comorbidities } \\
\hline Schizophrenia & 325 & 0.9 & 8,685 & 0.6 & 5,735 & 1.8 & 1,345 & 1.0 \\
\hline $\begin{array}{l}\text { Autism spectrum } \\
\text { disorders }\end{array}$ & 30 & 0.1 & 845 & 0.1 & 545 & 0.2 & 105 & 0.1 \\
\hline
\end{tabular}


medRxiv preprint doi: https://doi.org/10.1101/2021.12.29.21268235; this version posted January 1 , 2022. The copyright holder for this preprint (which was not certified by peer review) is the author/funder, who has granted medRxiv a license to display the preprint in

It is made available under a CC-BY-NC-ND 4.0 International license.

\begin{tabular}{|c|c|c|c|c|c|c|c|c|}
\hline \multirow[t]{2}{*}{ Characteristic } & \multicolumn{2}{|c|}{$\begin{array}{l}\text { VB-affected } \\
\text { deliveries, } \\
\mathrm{N}=37,085 \\
\text { ( } 35,517 \text { women) }\end{array}$} & \multicolumn{2}{|c|}{$\begin{array}{l}\text { VB-unaffected } \\
\text { deliveries, } \\
N=1,362,760 \\
\text { (783,020 women) }\end{array}$} & \multicolumn{2}{|c|}{$\begin{array}{l}\text { Terminations, } \\
\mathrm{N}=324,395 \\
(239,729 \text { women })\end{array}$} & \multicolumn{2}{|c|}{$\begin{array}{l}\text { Miscarriages, } \\
N=137,040 \\
(121,303 \text { women })\end{array}$} \\
\hline & $\mathbf{N}$ & $\%$ & $\mathbf{N}$ & $\%$ & $\mathbf{N}$ & $\%$ & $\mathbf{N}$ & $\%$ \\
\hline Neurotic disorders & 3,565 & 9.6 & 92,270 & 6.8 & 42,875 & 13.0 & 12,035 & 8.8 \\
\hline Eating disorders & 475 & 1.3 & 14,095 & 1.0 & 5,705 & 1.8 & 1,650 & 1.2 \\
\hline Personality disorder & 1,295 & 3.5 & 31,330 & 2.3 & 19,185 & 5.9 & 4,740 & 3.5 \\
\hline Alcohol abuse history & 365 & 1.0 & 9,680 & 0.7 & 10,315 & 3.2 & 1,990 & 1.5 \\
\hline $\begin{array}{l}\text { History of any } \\
\text { psychiatric condition } \\
\text { Medication use }\end{array}$ & 5,005 & 13.0 & 140,570 & 10.0 & 61,990 & 19.0 & 17,730 & 13.0 \\
\hline \multicolumn{9}{|c|}{ At least one prescription any time before the index date } \\
\hline Antipsychotics & 995 & 2.7 & 28,560 & 2.1 & 14,225 & 4.4 & 4,355 & 3.2 \\
\hline $\begin{array}{l}\text { Mood disorders } \\
\text { medication }\end{array}$ & 4,370 & 12.0 & 140,965 & 10.0 & 50,355 & 16.0 & 18,050 & 13.0 \\
\hline Antiepileptics & 765 & 2.1 & 24,320 & 1.8 & 8,540 & 2.6 & 3,185 & 2.3 \\
\hline ADHD medication & 135 & 0.4 & 4,825 & 0.4 & 3,375 & 1.0 & 645 & 0.5 \\
\hline NSAIDs & 18,830 & 51.0 & 664,725 & 49.0 & 153,020 & 47.0 & 71,930 & 52.0 \\
\hline Aspirin & 180 & 0.5 & 6,475 & 0.5 & 1,260 & 0.4 & 730 & 0.5 \\
\hline $\begin{array}{l}\text { Thyroid disorders } \\
\text { medication }\end{array}$ & 670 & 1.8 & 25,295 & 1.9 & 4,410 & 1.4 & 2,745 & 2.0 \\
\hline $\begin{array}{l}\text { Steroids for systemic } \\
\text { use }\end{array}$ & 2,850 & 7.7 & 103,830 & 7.6 & 20,780 & 6.4 & 11,375 & 8.3 \\
\hline $\begin{array}{l}\text { Anti-infectives for } \\
\text { systemic use }\end{array}$ & 32,055 & 86.0 & $1,180,555$ & 87.0 & 281,690 & 87.0 & 119,110 & 87.0 \\
\hline \multicolumn{9}{|c|}{ Within 30 days before the index date } \\
\hline $\begin{array}{l}\text { Anti-infectives for } \\
\text { systemic use }\end{array}$ & 2,950 & 8.0 & 81,605 & 6.0 & 33,290 & 10.0 & 10,160 & 7.4 \\
\hline Antiepileptics & 110 & 0.3 & 3,525 & 0.3 & 1,560 & 0.5 & 470 & 0.3 \\
\hline Antidepressants & 280 & 0.8 & 7,575 & 0.6 & 7,360 & 2.3 & 1,730 & 1.3 \\
\hline CVD medication ${ }^{b}$ & 380 & 1.0 & 43,980 & 3.2 & 3,155 & 1.0 & 1,805 & 1.3 \\
\hline NSAIDs & 230 & 0.6 & 1,950 & 0.1 & 5,995 & 1.8 & 1,790 & 1.3 \\
\hline
\end{tabular}

${ }^{a}$ Observations with missing women's age were excluded from the analyses

${ }^{b}$ CVD medications included clopidogrel, statins, any of antihypertensives 
medRxiv preprint doi: https://doi.org/10.1101/2021.12.29.21268235; this version posted January 1, 2022. The copyright holder for this preprint (which was not certified by peer review) is the author/funder, who has granted medRxiv a license to display the preprint in

It is made available under a CC-BY-NC-ND 4.0 International license .

Table 2. Cumulative incidences and incidence rates of any cancer, haematological, immunerelated, smoking and alcohol-related, and obesity-related cancers following vaginal bleedingaffected deliveries, vaginal bleeding-unaffected deliveries, and pregnancies ending in a termination or miscarriage, 1995-2017

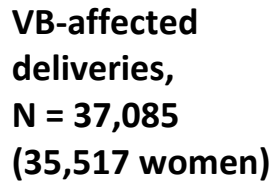

\author{
VB-unaffected \\ deliveries, \\ $N=1,362,760$ \\ (783,020 women)
}

Terminations,

$\mathrm{N}=324,395$

(239,729 women)
Miscarriages,

$\mathrm{N}=137,040$

(121,303

women)

\begin{tabular}{|c|c|c|c|c|}
\hline & $\mathrm{N}$, events $^{\mathrm{a}}$ & & & \\
\hline \multicolumn{5}{|l|}{ Any cancer } \\
\hline All pregnancies & 1,725 & 52,620 & 12,925 & 6,080 \\
\hline First pregnancies & 455 & 16,340 & 2,720 & 1,380 \\
\hline \multicolumn{5}{|c|}{ Haematological cancers } \\
\hline All pregnancies & 50 & 1,675 & 455 & 235 \\
\hline First pregnancies & 15 & 545 & 95 & 50 \\
\hline \multicolumn{5}{|c|}{ Immune-related cancers } \\
\hline All pregnancies & 870 & 26,935 & 6,320 & 2,840 \\
\hline First pregnancies & 225 & 8,760 & 1,495 & 695 \\
\hline \multicolumn{5}{|c|}{ Smoking and alcohol-related cancers } \\
\hline All pregnancies & 90 & 2,490 & 935 & 370 \\
\hline First pregnancies & 25 & 600 & 120 & 60 \\
\hline \multicolumn{5}{|c|}{ Obesity-related cancers } \\
\hline All pregnancies & 605 & 18,565 & 4,360 & 2,280 \\
\hline First pregnancies & 160 & 5,500 & 825 & 490 \\
\hline \multicolumn{5}{|l|}{ Other cancers } \\
\hline All pregnancies & 110 & 2,960 & 855 & 360 \\
\hline First pregnancies & 30 & 930 & 185 & 85 \\
\hline \multicolumn{5}{|c|}{ Selected site-specific cancers } \\
\hline \multicolumn{5}{|l|}{ All pregnancies } \\
\hline Breast cancer & 475 & 14,540 & 3,340 & 1,795 \\
\hline Cervical cancer & 105 & 3,430 & 955 & 315 \\
\hline $\begin{array}{l}\text { Ovary and } \\
\text { fallopian tube } \\
\text { cancer }\end{array}$ & 30 & 760 & 215 & 110 \\
\hline Uterine cancer & 15 & 495 & 105 & 65 \\
\hline \multicolumn{5}{|c|}{ Cumulative incidences, \% } \\
\hline \multicolumn{5}{|l|}{ Any cancer } \\
\hline All pregnancies & $9.9(9.2-10.6)$ & $9.9(9.8-10.1)$ & $9.3(9.1-9.6)$ & $10.3(9.9-10.8)$ \\
\hline First pregnancies & $9.1(7.9-10.4)$ & $8.7(8.5-9.0)$ & $6.4(6.0-6.9)$ & $8.1(7.5-8.7)$ \\
\hline \multicolumn{5}{|c|}{ Haematological cancers } \\
\hline All pregnancies & $0.3(0.2-0.5)$ & $0.3(0.3-0.3)$ & $0.3(0.3-0.4)$ & $0.4(0.3-0.5)$ \\
\hline First pregnancies & $0.2(0.1-0.5)$ & $0.3(0.2-0.3)$ & $0.2(0.1-0.2)$ & $0.2(0.2-0.4)$ \\
\hline \multicolumn{5}{|c|}{ Immune-related cancers } \\
\hline All pregnancies & $4.7(4.3-5.2)$ & $4.8(4.7-4.9)$ & $4.2(4.1-4.4)$ & $4.6(4.3-4.9)$ \\
\hline First pregnancies & $4.3(3.6-5.2)$ & $4.5(4.3-4.6)$ & $3.2(2.9-3.4)$ & $3.9(3.5-4.3)$ \\
\hline \multicolumn{5}{|c|}{ Smoking and alcohol-related cancers } \\
\hline All pregnancies & $0.6(0.4-0.7)$ & $0.6(0.6-0.7)$ & $0.9(0.8-1.1)$ & $0.8(0.7-0.9)$ \\
\hline
\end{tabular}


medRxiv preprint doi: https://doi.org/10.1101/2021.12.29.21268235; this version posted January 1,2022 . The copyright holder for this preprint (which was not certified by peer review) is the author/funder, who has granted medRxiv a license to display the preprint in It is made available under a CC-BY-NC-ND 4.0 International license .

$\begin{array}{ll}\begin{array}{l}\text { VB-affected } \\ \text { deliveries, }\end{array} & \begin{array}{l}\text { VB-unaffected } \\ \text { deliveries, }\end{array} \\ \mathbf{N}=\mathbf{3 7 , 0 8 5} & \mathrm{N}=\mathbf{1 , 3 6 2 , 7 6 0} \\ \text { (35,517 women) } & (\mathbf{7 8 3 , 0 2 0} \text { women) }\end{array}$

\begin{tabular}{|c|c|c|c|c|}
\hline First pregnancies & $0.6(0.4-1.1)$ & $0.4(0.4-0.5)$ & $0.5(0.3-0.7)$ & $0.4(0.3-0.6)$ \\
\hline \multicolumn{5}{|c|}{ Obesity-related cancers } \\
\hline All pregnancies & $3.7(3.3-4.2)$ & $3.6(3.5-3.7)$ & $3.2(3.1-3.4)$ & $4.0(3.7-4.3)$ \\
\hline First pregnancies & $3.4(2.6-4.4)$ & $3.1(3.0-3.3)$ & $2.2(1.9-2.5)$ & $3.1(2.7-3.6)$ \\
\hline \multicolumn{5}{|l|}{ Other cancers } \\
\hline All pregnancies & $0.6(0.5-0.8)$ & $0.5(0.5-0.6)$ & $0.6(0.5-0.7)$ & $0.6(0.5-0.7)$ \\
\hline First pregnancies & $0.5(0.3-0.8)$ & $0.5(0.4-0.6)$ & $0.4(0.3-0.5)$ & $0.4(0.3-0.5)$ \\
\hline \multicolumn{5}{|c|}{ Incidence Rate, 10000 PYs (95\% Cl) } \\
\hline \multicolumn{5}{|l|}{ Any cancer } \\
\hline All pregnancies & $\begin{array}{l}32.10 \text { (30.61- } \\
33.64)\end{array}$ & $\begin{array}{l}31.45 \text { (31.18- } \\
31.72)\end{array}$ & $30.10(29.58-30.62)$ & $\begin{array}{l}34.27 \text { (33.42- } \\
35.14) \\
\end{array}$ \\
\hline First pregnancies & $\begin{array}{l}28.71 \text { (26.17- } \\
31.44)\end{array}$ & $\begin{array}{l}27.25 \text { (26.83- } \\
27.67)\end{array}$ & $19.11(18.40-19.83)$ & $\begin{array}{l}26.80 \text { (25.41- } \\
28.24)\end{array}$ \\
\hline \multicolumn{5}{|c|}{ Haematological cancers } \\
\hline All pregnancies & $0.95(0.71-1.24)$ & $1.00(0.96-1.05)$ & $1.06(0.97-1.16)$ & $1.31(1.15-1.49)$ \\
\hline First pregnancies & $0.82(0.46-1.36)$ & $0.91(0.83-0.99)$ & $0.68(0.56-0.83)$ & $0.93(0.70-1.23)$ \\
\hline \multicolumn{5}{|c|}{ Immune-related cancers } \\
\hline All pregnancies & $\begin{array}{l}16.20 \text { (15.15- } \\
17.30)\end{array}$ & $\begin{array}{l}16.10 \text { (15.90- } \\
16.29)\end{array}$ & $14.72(14.36-15.08)$ & $\begin{array}{l}16.00(15.42- \\
16.60) \\
\end{array}$ \\
\hline First pregnancies & $\begin{array}{l}14.20 \text { (12.44- } \\
16.14) \\
\end{array}$ & $\begin{array}{l}14.61(14.31- \\
14.92) \\
\end{array}$ & $10.50(9.98-11.04)$ & $\begin{array}{l}13.47(12.49- \\
14.50) \\
\end{array}$ \\
\hline \multicolumn{5}{|c|}{ Smoking and alcohol-related cancers } \\
\hline All pregnancies & $1.64(1.32-2.01)$ & $1.49(1.43-1.55)$ & $2.18(2.05-2.32)$ & $2.07(1.87-2.30)$ \\
\hline First pregnancies & $1.63(1.09-2.36)$ & $1.00(0.92-1.08)$ & $0.84(0.70-1.00)$ & $1.20(0.93-1.53)$ \\
\hline \multicolumn{5}{|c|}{ Obesity-related cancers } \\
\hline All pregnancies & $\begin{array}{l}11.25 \text { (10.38- } \\
12.17)\end{array}$ & $\begin{array}{l}11.09 \text { (10.93- } \\
11.25)\end{array}$ & $10.15(9.85-10.45)$ & $\begin{array}{l}12.84(12.32- \\
13.38) \\
\end{array}$ \\
\hline First pregnancies & $\begin{array}{l}10.05 \text { (8.58- } \\
11.70)\end{array}$ & $9.18(8.94-9.42)$ & $5.80(5.41-6.20)$ & $\begin{array}{l}9.50(8.69- \\
10.37) \\
\end{array}$ \\
\hline \multicolumn{5}{|l|}{ Other cancers } \\
\hline All pregnancies & $2.06(1.71-2.48)$ & $1.77(1.71-1.83)$ & $1.99(1.86-2.12)$ & $2.04(1.83-2.25)$ \\
\hline First pregnancies & $2.01(1.40-2.80)$ & $1.55(1.45-1.65)$ & $1.28(1.11-1.48)$ & $1.69(1.36-2.07)$ \\
\hline \multicolumn{5}{|c|}{ Selected site-specific cancers } \\
\hline \multicolumn{5}{|l|}{ All pregnancies } \\
\hline Breast cancer & $\begin{array}{l}8.85(8.08- \\
9.67) \\
\end{array}$ & $8.70(8.56-8.84)$ & $7.80(7.54-8.07)$ & $\begin{array}{l}10.14 \text { (9.67- } \\
10.61) \\
\end{array}$ \\
\hline Cervical cancer & $\begin{array}{l}1.94(1.59- \\
2.34) \\
\end{array}$ & $2.05(1.99-2.12)$ & $2.23(2.09-2.37)$ & $1.79(1.60-2.00)$ \\
\hline $\begin{array}{l}\text { Ovary and } \\
\text { fallopian tube } \\
\text { cancer }\end{array}$ & $\begin{array}{l}0.60(0.42- \\
0.83)\end{array}$ & $0.45(0.42-0.49)$ & $0.50(0.44-0.57)$ & $0.62(0.51-0.75)$ \\
\hline Uterine cancer & $\begin{array}{l}0.26(0.15- \\
0.43)\end{array}$ & $0.30(0.27-0.32)$ & $0.25(0.20-0.30)$ & $0.37(0.29-0.47)$ \\
\hline
\end{tabular}

Terminations,

$\mathrm{N}=324,395$

(239,729 women)

Miscarriages,

$\mathrm{N}=137,040$

(121,303

women) 
medRxiv preprint doi: https://doi.org/10.1101/2021.12.29.21268235; this version posted January 1, 2022. The copyright holder for this preprint (which was not certified by peer review) is the author/funder, who has granted medRxiv a license to display the preprint in It is made available under a CC-BY-NC-ND 4.0 International license .

Table 3. Hazard ratios (HRs) with 95\% confidence intervals (Cls) for any cancer, 1995-2017 Model HR $(95 \% \mathrm{Cl})$

\begin{tabular}{|c|c|c|}
\hline \multicolumn{3}{|c|}{ VB-affected deliveries vs VB-unaffected deliveries ${ }^{a}$} \\
\hline \multirow{3}{*}{ All pregnancy records } & Crude & $0.96(0.91-1.01)$ \\
\hline & Conventionally adjusted ${ }^{\mathrm{b}}$ & $0.97(0.92-1.01)$ \\
\hline & ATT-weightedc & $0.98(0.93-1.03)$ \\
\hline \multirow{3}{*}{ First pregnancy records } & Crude & $0.99(0.91-1.09)$ \\
\hline & Conventionally adjusted $^{\mathrm{b}}$ & $0.97(0.88-1.06)$ \\
\hline & ATT-weighted ${ }^{c}$ & $0.98(0.90-1.08)$ \\
\hline \multicolumn{3}{|c|}{ VB-affected deliveries vs terminations $^{d}$} \\
\hline \multirow{3}{*}{ All pregnancy records } & Crude & $1.02(0.97-1.08)$ \\
\hline & Conventionally adjusted $^{\mathrm{b}}$ & $0.88(0.77-1.00)$ \\
\hline & ATT-weightedc & $1.00(0.94-1.06)$ \\
\hline \multirow{3}{*}{ First pregnancy records } & Crude & $1.45(1.31-1.60)$ \\
\hline & Conventionally adjusted $^{\mathrm{b}}$ & $0.88(0.68-1.13)$ \\
\hline & ATT-weightedc & $0.95(0.83-1.08)$ \\
\hline \multicolumn{3}{|c|}{ VB-affected deliveries vs miscarriages $^{d}$} \\
\hline \multirow{3}{*}{ All pregnancy records } & Crude & $0.89(0.84-0.93)$ \\
\hline & Conventionally adjusted $^{\mathrm{b}}$ & $0.90(0.79-1.02)$ \\
\hline & ATT-weighted ${ }^{c}$ & $1.04(0.94-1.14)$ \\
\hline \multirow{3}{*}{ First pregnancy records } & Crude & $1.01(0.91-1.13)$ \\
\hline & Conventionally adjusted $^{b}$ & $1.02(0.80-1.32)$ \\
\hline & ATT-weighted ${ }^{c}$ & $1.16(1.02-1.32)$ \\
\hline
\end{tabular}

${ }^{a}$ Adjusted for age, calendar year of pregnancy end, women's parity, smoking socioeconomic factors (education, employment, and year-specific income level divided into quartiles based on all included pregnancies), reproductive history (previous episodes of vaginal bleeding, pregnancy terminations and miscarriages), chronic somatic and psychiatric conditions, and women's medication use before the index date available from 1995 (as a proxy for overall underlying health and healthcare-seeking behaviour).

${ }^{b}$ Models were adjusted using multivariable Cox proportional hazards regression.

${ }^{\mathrm{C}}$ ATT-weighted and conventionally adjusted models included the same adjustment set of covariables.

${ }^{d}$ Analyses could not be adjusted for smoking or body mass index since the data on these covariables are unavailable for pregnancies ending in a termination or miscarriage. 
medRxiv preprint doi: $h t t p s: / / d o i . o r g / 10.1101 / 2021.12 .29 .21268235$; this version posted January 1 , 2022. The copyright holder for this preprint (which was not certified by peer review) is the author/funder, who has granted medRxiv a license to display the preprint in It is made available under a CC-BY-NC-ND 4.0 International license .

Table 4. Hazard ratios (HRs) with $95 \%$ confidence intervals (Cls) for haematological, immunerelated, smoking and alcohol-related, and obesity-related cancers, 1995-2017

Outcome

HR $(95 \% \mathrm{Cl})$

VB-affected deliveries vs VB-unaffected deliveries ${ }^{\mathrm{a}}$

\begin{tabular}{lll}
\hline \multirow{2}{*}{ Haematological cancers } & All pregnancies & $0.91(0.69-1.20)$ \\
\cline { 2 - 3 } & First pregnancies & $0.85(0.49-1.48)$ \\
\hline \multirow{2}{*}{ Immune-related cancers } & All pregnancies & $0.99(0.93-1.06)$ \\
\cline { 2 - 3 } & First pregnancies & $0.93(0.81-1.06)$ \\
\hline \multirow{2}{*}{ Smoking and alcohol-related cancers } & All pregnancies & $0.92(0.74-1.14)$ \\
\cline { 2 - 3 } & First pregnancies & $1.38(0.93-2.04)$ \\
\hline \multirow{2}{*}{ Obesity-related cancers } & All pregnancies & $0.96(0.88-1.04)$ \\
\cline { 2 - 3 } Other cancers & First pregnancies & $1.00(0.85-1.17)$ \\
\cline { 2 - 3 } & All pregnancies & $1.08(0.89-1.31)$ \\
\cline { 2 - 3 } & First pregnancies & $1.22(0.86-1.74)$ \\
\hline
\end{tabular}

VB-affected deliveries vs terminations ${ }^{\mathrm{b}}$

\begin{tabular}{lll}
\hline \multirow{2}{*}{ Haematological cancers } & All pregnancies & $0.83(0.60-1.16)$ \\
\cline { 2 - 3 } Immune-related cancers & First pregnancies & $0.71(0.36-1.38)$ \\
\hline \multirow{2}{*}{ Smoking and alcohol-related cancers } & All pregnancies & $0.94(0.87-1.02)$ \\
\cline { 2 - 3 } & First pregnancies & $0.84(0.72-0.99)$ \\
\hline \multirow{2}{*}{ Obesity-related cancers } & All pregnancies & $0.77(0.60-0.98)$ \\
\cline { 2 - 3 } & First pregnancies & $1.07(0.66-1.75)$ \\
\hline \multirow{2}{*}{ Other cancers } & All pregnancies & $0.92(0.84-1.01)$ \\
\cline { 2 - 3 } & First pregnancies & $0.92(0.76-1.12)$ \\
\hline \multirow{2}{*}{ VB-affected deliveries vs miscarriages ${ }^{b}$} & All pregnancies & $0.82(0.66-1.03)$ \\
\cline { 2 - 3 } & First pregnancies & $1.15(0.73-1.80)$ \\
\hline \multirow{2}{*}{ Haematological cancers } & All pregnancies & \\
\hline \multirow{2}{*}{ Immune-related cancers } & First pregnancies & $0.61(0.38-0.97)$ \\
\hline \multirow{2}{*}{ Smoking and alcohol-related cancers } & All pregnancies & $1.01(0.99-1.73)$ \\
\cline { 2 - 3 } & First pregnancies & $0.99(0.85-1.16)$ \\
\hline \multirow{2}{*}{ Obesity-related cancers } & All pregnancies & $0.64(0.47-0.88)$ \\
\cline { 2 - 3 } & First pregnancies & $1.50(0.93-2.41)$ \\
\hline \multirow{2}{*}{ Other cancers } & All pregnancies & $0.90(0.79-1.01)$ \\
\cline { 2 - 3 } & First pregnancies & $1.01(0.84-1.22)$ \\
\hline
\end{tabular}

adjusted for age, calendar year of pregnancy end, women's parity, smoking, socioeconomic factors (education, employment, and year-specific income level divided into quartiles based on all included pregnancies), reproductive history (previous episodes of vaginal bleeding, pregnancy terminations and miscarriages), chronic somatic and psychiatric conditions, and women's medication use before the index date available from 1995 (as a proxy for overall underlying health and healthcare-seeking behaviour).

${ }^{\mathrm{b}}$ Analyses could not be adjusted for smoking or body mass index since the data on these covariables are unavailable for pregnancies ending in a termination or miscarriage. 
medRxiv preprint doi: $h t t p s: / / d o i . o r g / 10.1101 / 2021.12 .29 .21268235$; this version posted January 1 , 2022. The copyright holder for this preprint (which was not certified by peer review) is the author/funder, who has granted medRxiv a license to display the preprint in It is made available under a CC-BY-NC-ND 4.0 International license .

Table 5. Hazard ratios (HRs) with $95 \%$ confidence intervals (Cls) for the risk of breast cancer, cervical cancer, ovarian and fallopian tube cancer, and uterine cancer, 1995-2017

\begin{tabular}{|c|c|c|}
\hline & Model & HR $(95 \% \mathrm{Cl})$ \\
\hline \multicolumn{3}{|c|}{ VB-affected deliveries vs VB-unaffected deliveries ${ }^{\mathrm{a}}$} \\
\hline \multirow{2}{*}{ Breast cancer } & Crude & $0.95(0.86-1.04)$ \\
\hline & Conventionally adjusted $^{b}$ & $0.94(0.86-1.03)$ \\
\hline \multirow{2}{*}{ Cervical cancer } & Crude & $0.94(0.77-1.15)$ \\
\hline & Conventionally adjusted $^{b}$ & $0.94(0.77-1.14)$ \\
\hline \multirow{2}{*}{ Ovarian and fallopian tube cancer } & Crude & $1.21(0.86-1.72)$ \\
\hline & Conventionally adjusted $^{\mathrm{b}}$ & $1.16(0.81-1.66)$ \\
\hline \multirow{2}{*}{ Uterine cancer } & Crude & $0.78(0.44-1.37)$ \\
\hline & Conventionally adjusted $^{b}$ & $0.78(0.46-1.33)$ \\
\hline \multicolumn{3}{|c|}{ VB-affected deliveries vs terminations ${ }^{\mathrm{c}}$} \\
\hline \multirow{2}{*}{ Breast cancer } & Crude & $1.08(0.98-1.19)$ \\
\hline & Conventionally adjusted $^{b}$ & $0.98(0.88-1.08)$ \\
\hline \multirow{2}{*}{ Cervical cancer } & Crude & $0.86(0.70-1.06)$ \\
\hline & Conventionally adjusted $^{b}$ & $0.80(0.65-0.99)$ \\
\hline \multirow{2}{*}{ Ovarian and fallopian tube cancer } & Crude & $1.12(0.78-1.63)$ \\
\hline & Conventionally adjusted $^{b}$ & $0.92(0.63-1.37)$ \\
\hline \multirow{2}{*}{ Uterine cancer } & Crude & $0.98(0.54-1.77)$ \\
\hline & Conventionally adjusted $^{b}$ & $0.97(0.54-1.74)$ \\
\hline \multicolumn{3}{|c|}{ VB-affected deliveries vs miscarriages ${ }^{c}$} \\
\hline \multirow{2}{*}{ Breast cancer } & Crude & $0.82(0.74-0.91)$ \\
\hline & Conventionally adjusted $^{b}$ & $0.95(0.84-1.06)$ \\
\hline \multirow{2}{*}{ Cervical cancer } & Crude & $1.08(0.86-1.35)$ \\
\hline & Conventionally adjusted $^{b}$ & $0.98(0.75-1.27)$ \\
\hline \multirow{2}{*}{ Ovarian and fallopian tube cancer } & Crude & $0.90(0.62-1.32)$ \\
\hline & Conventionally adjusted $^{\mathrm{b}}$ & $0.88(0.56-1.38)$ \\
\hline \multirow{2}{*}{ Uterine cancer } & Crude & $0.63(0.34-1.16)$ \\
\hline & Conventionally adjusted $^{b}$ & $0.65(0.34-1.24)$ \\
\hline
\end{tabular}

${ }^{a}$ Adjusted for age, calendar year of pregnancy end, women's parity, smoking, socioeconomic factors (education, employment, and year-specific income level divided into quartiles based on all included pregnancies), reproductive history (previous episodes of vaginal bleeding, pregnancy terminations and miscarriages), chronic somatic and psychiatric conditions, and women's medication use before the index date available from 1995 (as a proxy for overall underlying health and healthcare-seeking behaviour)

${ }^{\mathrm{b}}$ Analyses were adjusted using multivariable Cox proportional hazard regression

${ }^{c}$ Analyses could not be adjusted for smoking or body mass index since the data on these covariables are unavailable for pregnancies ending in a termination or miscarriage 
$\checkmark$

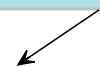

2,829,027 records:

$\mathrm{N}$, women $=1,443,429$

Still- and live births in Denmark, 1973-2017:

Including 89,723 infants born from multi-fetal deliveries

$$
\text { 2,816,212 Live birth }
$$

\section{3,528 records:}

Vaginal bleeding hospital diagnoses, the DNPR

Excluded: Non-unique identifiers of the children $(\mathrm{N}=15)$

One identifier randomly selected for each multi-fetal delivery is kept $(N=44,458)$ 2,783,747 records:
2,771,570 Live birth

12,177 Stillbirths
(1977-2018); N, women $=120,697$

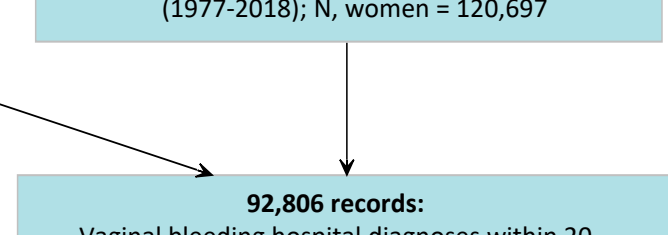

Vaginal bleeding hospital diagnoses within 20 gestational weeks; $N$, women $=67,555$

\section{4,405 records: \\ Hospital encounters for miscarriages, the DNPR: \\ $\mathrm{N}$, women $=243,743$

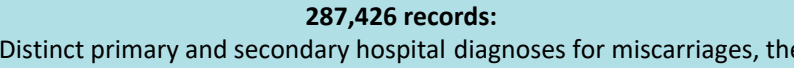 DNPR N, women $=243,743$}

\section{Excluded records:}

402,068 Records outside of the period 1979-2017
747,237 records:

Hospital diagnoses for pregnancy terminations, the

DNPR (1979-2018); N, women $=453,396$

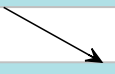

\section{1,974 records:}

Records of procedures for pregnancy terminations, the DNPR; N, women $=183,804$

ing in still- and live births, 1979-2017

$\mathrm{N}$, women $=1,240,002$

\section{6,224 records}

Distinct records for pregnancy terminations, the DNPR

$\mathrm{N}$, women $=465,813$

$\leftarrow$

408,135 Pregnancy records:

$\mathrm{N}$, women $=1,411,869$

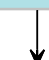

\section{Excluded 1,546,862 records:}

14,511 Repeated episodes of vaginal bleeding in pregnancy

71,450 Unknown gestational age

6749 Encounters for different reproductive events (delivery, miscarriage, termination, vaginal bleeding) registered on the same date

67,923 Dates of encounters for reproductive events (delivery, miscarriage, termination, vaginal bleeding) after 2017

1,292,491 Pregnancies before 1995

70,897 Excluded from childbirths due to vaginal bleeding episode

13,752 History of cancer before the index date

957 History of AIDS before the index date

8,132 Personal identifier not found in the CRS or emigrated before the index date

Final study population (clouded counts)

$\mathbf{1 , 8 6 1 , 2 7 5}$ pregnancies (1995-2017) of 887,759 distinct women

$1,362,760$ Pregnancies unaffected by vaginal bleeding and ending in childbirths (783,020 women)

37,085 Pregnancies affected by vaginal bleeding within 20 gestational weeks and ending in childbirths (35,517 women)

324,395 Pregnancies ending in a termination (239,729 women)

137,040 Pregnancies ending in a miscarriage (121,303 women) 